
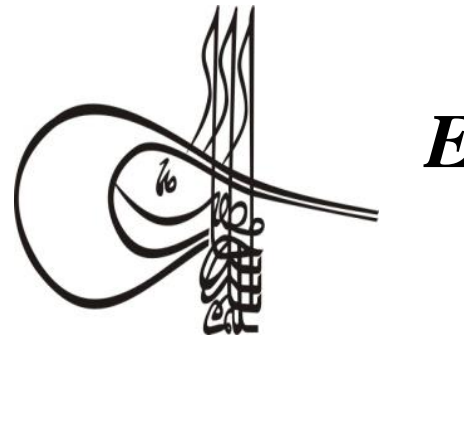

Received/Geliş: 19.04.2019

Turkigh Studies

Economics, Finance, Politics

Volume 14 Issue 2, 2019, p. 395-406

DOI: 10.29228/TurkishStudies.22939

ISSN: 2667-5625

Skopje/MACEDONIA-Ankara/TURKEY

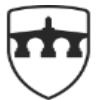

INTERNATIONAL

BALKAN

UNIVERSITY

EXCELLENCE FOR THE FUTURE IBU.EDU.MK

\author{
Research Article / Araştırma Makalesi
}

Article Info/Makale Bilgisi

\Accepted/Kabul: 10.06.2019

This article was checked by iThenticate.

\title{
HOW OIL PRICES IMPACT THE ECONOMIC GROWTH OF VENEZUELA?
}

\author{
Nazife Özge BEŞER*
}

\begin{abstract}
Energy, which is one of the indispensable elements of economic and social development, is provided by fossil resources such as coal, and natural gas. The coal, the main energy source of the First Industrial Revolution, was replaced by oil from the end of the 19th century. Although consumption patterns have changed over time and new energy sources have emerged, oil has not lost its importance today. Oil prices are one of the most important indicators of economic performance in the world and the country. In the last 45 years, the world economy, which has faced oil shocks, has increased its sensitivity to oil prices. For this reason, studies investigating the effects of oil prices on macroeconomic data have started to take place frequently in the literature and analysts have gained gains in the literature with different methods and approaches. The aim of this study was to determine the effect of the changes in oil prices on economic growth in Venezuela for the period 1980-2014. The reason for the fact that this period used in the analysis is limited with 2014 is due to the inaccessibility of these data. DickeyFuller Unit Root Test and Philips-perron Unit Root Tests were used in this study. When the series were found to be stationary at the first level, Johansen Cointegration Test was performed. As a result of the analysis, it is seen that there is a cointegration relationship between the variables in the long term, whereas in the causality research, one-way causality relationship from oil prices to economic growth has been determined. Then Granger Causality analysis was used.
\end{abstract}




\section{STRUCTURED ABSTRACT}

Oil prices are highly important indicators in terms of all countries' economies. Economies depend on directly or indirectly to oil. Therefore, a lot of macroeconomic growths has been affected at the result of oil shocks specific to both petroleum exporting countries and petroleum importing countries such as balance of payments, terms of trade, inflation level, real national income, exchange rate and bank rate. While increases in oil prices affect a lot of macroeconomic growths such as terms of trade, real national income, balance of payments in especially petroleum exporting countries, they have caused to financial crises, unemployment, decreasing in petroleum exporting and investing, and high inflation in different sectors. High oil prices have caused to decrease in domestic income of oil importing countries. Since it is not possible to decrease the oil consumption by rate of increase the rate of oil prices, oil expenses had increased and national income that was reserved for other expenses has declined. An increase in oil prices has ensured to rise of national income in oil exporting countries by arising reverse situation of oil importing countries.

In this regard, the purpose of this study is to analyze effects on growth of oil prices for Venezuela by the help of Johansen Cointegration Test and Granger Causality Test by using annual data in between 19802014. The reason for the fact that this period used in the analysis is limited with 2014 is due to the inaccessibility of these data. Dickey-Fuller Unit Root Test and Philips-perron Unit Root Tests were used in this study. When the series were found to be stationary at the first level, Johansen Cointegration Test was performed. As a result of the analysis, it is seen that there is a cointegration relationship between the variables in the long term, whereas in the causality research, one-way causality relationship from oil prices to economic growth has been determined. Then Granger Causality analysis was used.

It has been thought that the study will contribute to literature since researches conducted are in mostly bloc although there are a lot of studies about this subject in literature and there isn't much studies with Venezuela. Research has been consisted of four chapters and in the second chapter after this one, it has been given place to studies that examine relation with oil prices and economic growth; in the third chapter, empirical application of study has been done and; in the last chapter, research has been completed with result and suggestions.

In conducted study, it had been determined that oil prices, GDP, capital and labor variables are not stationary series and they are first order integrated series by applied unit root tests. Johansen cointegration analysis that enables to search long term relation since series are same order integrated had been performed. In the analysis result, it had been established that series move together in long term. Then, Granger causality test had been done between series and it had been found that there is a unidirectional causality relation between oil prices and economic growth. For this reason, politics that was in direction to increase oil production in Venezuela are going to be effective on economic growth. 
Oil, which is a part of basic energy resources, has a very important place in our daily life. Nearly all sectors use oil as input, either directly or indirectly. As a consequence of this dependence, oil prices have an impact on both the country and the world economy.

Oil is the most important energy source. Hence, increases in oil prices have indirect and direct implications on the economies of developed and developing countries. The negative effects of the increase in oil prices on the economy are increasing in direct proportion to the share of oil spending in national income and the fact that the country cannot turn to other energy sources.

Venezuela should develop more industrial sectors. The industrial sector should invest more in development, especially in the current economic system reforms should go to encourage foreign capital. The share of human capital investment should also be increased in order to raise quality human power. Work to be done in various areas should be encouraged. Nowadays, priority is given to the natural gas sector, which is increasing in importance.

Keywords: Granger Causality Analysis, Johansen Cointegration Test, Oil Prices, Time Series Analysis, Venezuela

\section{PETROL FIYATLARI VENEZUELA'NIN EKONOMIK BÜYÜMESINI NASIL ETKILER?}

\section{öz}

Ekonomik ve sosyal kalkınmanın vazgeçilmez unsurlarından biri olan enerji günümüzde, başta petrol olmak üzere kömür ve doğalgaz gibi önemli ölçüde fosil kaynaklarından sağlanmaktadır. Birinci Sanayi Devriminin temel enerji kaynağı olan kömürün yerini 19. Yüzyıl sonundan itibaren petrol almıştır. Tüketim kalıplarının zamanla değişmiş ve yeni enerji kaynakları ortaya çıkmış olmasına rağmen, petrol önemini günümüzde de kaybetmemiştir. Petrol fiyatları, dünya ve ülke ekonomik performansı açısından önemli göstergelerden birisidir. Son 45 yıllık süreç içerisinde ise petrol şokları ile karşı karşıya kalan dünya ekonomisinin petrol fiyatlarına karşı hassasiyeti artmıştır. $\mathrm{Bu}$ sebeple, petrol fiyatlarının makroekonomik veriler üzerindeki etkilerini inceleyen çalışmalar literatürde sıklıkla yer almaya başlamış olup, analizciler farklı yöntem ve yaklaşımlarla literatüre kazanımlar sağlamışlardır. Bu çalışmanın amacı, Venezuela'da 1980-2014 dönemi için petrol fiyatlarındaki değişikliklerin ekonomik büyüme üzerinde ne gibi bir etkisinin olduğu ekonometrik açıdan tespit edilmeye çalışılmıştır. Analizde kullanılan bu dönemin 2014 yılı ile kisıtlı kalmasının nedeni bu verilere ulaşılamamasından kaynaklanmaktadır. Çalışmada öncelikle serilerin durağanlıklarının analiz edilmesi üzerine Dickey-Fuller Birim Kök testi ve Philips-perron Birim Kök testlerinden yararlanılmıștır. Serilerin birinci seviyesinde durağan olduklarının görülmesi üzerine Johansen Eşbütünleşme Testi yapılmıştır. Daha sonra Granger Nedensellik analizi kullanılmış olup analiz sonucunda değişkenler arasında uzun dönemde eşbütünleşme ilişkisi olduğu görülürken, nedensellik araştırmasında ise petrol fiyatlarından ekonomik büyümeye doğru tek yönlü nedensellik ilişkisi tespit edilmiştir.

Turkish Studies - Economics, Finance, Politics

Volume 14 Issue 2, 2019 
Anahtar Kelimeler: Granger Nedensellik Analizi, Johansen Eşbütünleşme Testi, Venezüella, Petrol Fiyatları, Zaman Serileri Analizi.

\section{Introduction}

Oil which is at the head of nonrenewable energy sources is one of irreplaceable factors of economic and social progress. The price of oil which takes an important place in world energy resources is an important indicator in terms of economic performance of countries. Naturally, the greater and the longer increase in oil prices, the impact on macroeconomic variables has been much bigger.

Oil prices are highly important indicators in terms of all countries' economies. Economies depend on directly or indirectly to oil. Therefore, a lot of macroeconomic growths has been affected at the result of oil shocks specific to both petroleum exporting countries and petroleum importing countries such as balance of payments, terms of trade, inflation level, real national income, exchange rate and bank rate. While increases in oil prices affect a lot of macroeconomic growths such as terms of trade, real national income, balance of payments in especially petroleum exporting countries, they have caused to financial crises, unemployment, decreasing in petroleum exporting and investing, and high inflation in different sectors. High oil prices have caused to decrease in domestic income of oil importing countries. Since it is not possible to decrease the oil consumption by rate of increase the rate of oil prices, oil expenses had increased and national income that was reserved for other expenses has declined. An increase in oil prices has ensured to rise of national income in oil exporting countries by arising reverse situation of oil importing countries.

\section{Literature Review}

There are a lot of empirical study that examine relation of changes of oil prices with economic variables in economy literature. The macroeconomic effects of changes in oil prices had been searched practically by Lienert firstly in 1981. In conducted study, short-term results of increases of oil prices had been searched for Denmark, Finland, Norway and Sweden. Oil price rises had result in loss of production in countries except Finland in between years of 1979-1980. Reason is that export of Finland to Soviet Union balances commercial loss (Lienert, 1981:201).

One of important studies that examines relation between oil prices and economic growth is the analysis that made by Hamilton (1983). Hamilton had come to conclusion that rises in oil prices caused decline in growth of real GNP by using Granger Causality analysis in study that he made by using trimester data between 1948:2 and 1980:3 for USA.

Burbidge and Harrison (1984) had examined the effect of oil prices on inflation and industrial outcome by VAR model in study that they made for USA, Japan, Germany, United Kingdom and Canada in between 1962-1982. In the result of study, it has been concluded that there is negative and significant effect of oil and energy shocks on real activity. While effect of oil and energy shocks on real activity is determinant in wide area in USA and England, it had been concluded to that there is less effect in other countries.

Mork (1989) had examined effects of oil prices on economic growth of America by the help of Granger Causality method. Results had shown that oil prices affect the growth of America in negative direction.

Brown and Yücel (1999) had used action and reaction function in the study that relation was guessed between oil price shocks and economic growth in USA between 1965-1997. Result has shown that increases in oil prices cause decrease in real GDP and increases in interest rates and price level.

Papapetrou (2001) had investigated the relation between oil prices, real share prices, interest rates, real economic activity and employment within the scope of multivariate VAR model in Greece 
between eras of 1989-1999. Obtained results had shown that there are negative effects of oil prices and industrial production and employment.

Lardic and Mignon (2006) had concluded that there is asymmetric cointegration relation between oil prices and economic growth in study that was examined whether there is long term relation between economic growth and oil prices or not. This result means that decline in economy caused by increasing oil prices is more than recovery when it decreased.

Blanchard and Gali (2007) has researched effects of changes in oil prices on USA, Germany, France, England, Italy and Japan and effect on industrial production level. According to this result, it has been found that effect of changes in oil prices on industrial production level is low.

Lardic S. and Mignon V. (2008) had concluded that there is asymmetric cointegration while standard cointegration was rejected in the study that whether there is a long-term relation between oil prices and economic activity or not in G-7, Europe Region countries and United States countries. This result has been determined also in G-7 and Europe Region countries not only in America countries.

Hanabusa K. (2009) had examined the relation between oil prices and economic growth between the years of 2000 and 2008 by generalized autoregressive conditional heteroskedasticity method. Empirical results have shown that oil prices are Granger cause of economic growth.

Miller J. I and Ratti R.A. (2009) had searched that whether there is long term relation between crude oil prices and international stock markets in 6 OECD countries between years of 1971 and 1998 or not. They had used cointegrated vector error correction model in commited empirical study. At the result of empirical analyses, they had concluded to that there is positive relation between crude oil prices and international stock markets.

Lorde, Jackman and Thomas (2009), had used Granger causality analysis in the study that they examined the macroeconomic reasons of fluctuations in oil prices for Tirinidad and Tobago between 1996 and 2005. In consequence of study, they had determined that there is causality relation from oil prices to public revenues and outcome.

Berument and others (2010) had searched the effect of a shock in oil prices on economic growth in these 16 MENA countries as empirically by the help of Vector Autoregressive model for these countries. While obtained results were showing that oil prices have a statically significant and positive effect on outcomes of Algeria, Iran, Iraq, Kuwait, Libya, Oman, Qatar, Syria and United Arab Emirates, they have not a statically significant effect on Bahrain, Djibouti, Egypt, Israel, Jordan, Morocco and Tunisia.

Abeysinghe T. (2011) had examined the effect of oil prices on economic growth in the analysis conducted for 12 chosen countries by the help of VAR model. Application results have shown that effect of oil prices on economic growth is not important in a big economy such USA but plays an important role in small open economies.

Jyaraman and Lau (2011) had researched effects of oil prices on economic growth in study that they conducted for 14 Pacific island countries. Obtained findings have shown that oil prices are cointegrated with economic growth and international reserves. While any causality relation has not been observed among variables in long term, a causality has been determined from oil prices to international reserves and economic growth in short term.

Cunado and Gracia (2013) had analyzed effects of oil prices on industrial production index and inflation rates for 15 European countries between years of 1960-1969 by help of Granger Causality Analysis. In the result of cointegration test conducted, it had been determined that there is not long term cointegration between oil price and economic activity. 
Nazir and Hameed (2015), had examined the effect of oil consumption on Pakistan's GDP by using annual data from 1972 to 2011. they used ADF and Johansen Maximum Likelihood method in the study. According to result the long run and dynamic relationship has not detected for industrial oil consumption and oil price variables for model has no short run impact on GDP.

Ftiti et al. (2016), had investigated the degree of interdependence between oil prices and economic activity growth for United Arab Emirates, Kuwait, Saudi Arabia, and Venezuela in the Organization of the Petroleum Exporting Countries (OPEC) over the period from 3 September 2000 to 3 December 2010. According to result that oil price shocks in periods during period of fluctuations in the global business cycle and financial turmoil affected the relationship between oil and economic growth in OPEC countries.

Alagöz et al. (2017), had investigated the effects of oil prices on macroeconomic variables for 8 countries (Turkey, China, South Africa, Mexico, Colombia, Costa Rica, Indonesia and Kazakhstan) between years of 1980-2016 by help of panel data analysis. In the result of study a dollar increase in Crude Oil price caused a $0.04 \%$ increase in inflation across the countries examined. Increase in Crude Oil price, affecting as current account deficit by making a negative impact on the current account balance.

Albaity and Mustafa (2018), had investigated the long- and short-run relationships between oil prices and stock market returns, exchange rates, gold prices, and linear and non-linear output, for the six Gulf Cooperation Council (GCC) countries. Panel data and time series analysis were used in the study where monthly data were used between 2005 and 2015 and cointegration causality tests were used. The results indicated co-movement among these variables in the long run. The causality test shows a oneway relationship between oil prices and gross domestic product (GDP), and a two-way relationship between stock returns and oil prices.

In this regard, the purpose of this study is to analyze effects on growth of oil prices for Venezuela by the help of Johansen Cointegration Test and Granger Causality Test by using annual data in between 1980-2014. It has been thought that the study will contribute to literature since researches conducted are in mostly bloc although there are a lot of studies about this subject in literature and there isn't much studies with Venezuela. Research has been consisted of four chapters and in the second chapter after this one, it has been given place to studies that examine relation with oil prices and economic growth; in the third chapter, empirical application of study has been done and; in the last chapter, research has been completed with result and suggestions.

\section{Materials and Methods}

In study, annual data between 1980 and 2014 had been used as research period. The reason of this period which was used in analysis remained restricted had derived from not being reached to some variables which were used in analysis. GDP of Venezuela chosen in study had been included to model as dependent variable and world oil prices, employment rate, constant capital accumulation had been included as independent variables, and logarithms of all variables had been taken. Definitions of variables that were used in model and data resources of them had been indicated in following Table 1 .

Table 1. Identification of Definitions

\begin{tabular}{|l|l|c|}
\hline Variables & \multicolumn{1}{|c|}{ Explanations } & Resource \\
\hline $\operatorname{loggdp}$ & Gross Domestic Product (year of 2010 \$) & World Bank (WDI) \\
\hline $\operatorname{logop}$ & Brent crude oil prices & IEA \\
\hline loglab & Labour & World Bank (WDI) \\
\hline logcap & Constant capital accumulation & World Bank (WDI) \\
\hline
\end{tabular}




\subsection{Unit Root Tests}

\subsubsection{Dickey-Fuller Unit Root Test}

Stationary concept has emerged as an important situation in time series analysis. A time series is stable if average and variance of it does not change in time and covariance between two periods is dependent to only distance between two periods not to period that this covariance was calculated (Gujarati, 2011:713). Orders of stationary in this study have been examined by ADF and PP unit root tests that were in studies of Dickey and Fuller (1979) and Philips and Peron (1988), respectively.

Dickey-Fuller unit root test developed by Dickey-Fuller (1979-1981) is one of the common methods to examine whether a time series is stable or not. Regression equations developed for ADF test that was used for researching stationaries of series were as follows:

$$
\begin{aligned}
\Delta Y_{t} & =\rho Y_{t-1}+\sum_{i=1}^{k} \beta_{i} \Delta Y_{t-i}+\varepsilon_{t} \\
\Delta Y_{t} & =\alpha_{0}+\rho Y_{t-1}+\sum_{i=1}^{k} \beta_{i} \Delta Y_{t-i}+\varepsilon_{t} \\
\Delta Y_{t} & =\alpha_{0}+\beta_{t}+\rho Y_{t-1}+\sum_{i=1}^{k} \beta_{i} \Delta Y_{t-i}+\varepsilon_{t}
\end{aligned}
$$

Hypothesizes of unit root tests partaking in study are as follows:

$\mathrm{H}_{0}$ : unit root exists. Series is not stable.

$\mathrm{H}_{1}$ : Unit root does not exist. Series is stable.

$\mathrm{H}_{0}$ hypothesis has been rejected in $5 \%$ of significant level when probability value that will be obtained in the test result is smaller than 0.05 and it has been decided that series are stable.

\subsubsection{Philips-Perron Unit Root Test}

The fact that a majority of the time series do not have a static process, the statistic for examining the hypothesis has increased the relevance to the tests (Bozkurt, 2007). Philips-Perron (1989) is more powerful test than ADF unit root test and has measured stationary of series that include specially trend. Although ADF test has used same hypothesis and asymptotic distributions, it does not use lagged variables of series.

In the Phillips-Perron unit root test, the error term is weakly dependent and allows heterogeneous distribution (Enders, 2004). Regression equation developed for PP test that was used to examine stationaries of series is as follows:

$$
\Delta Y_{t}=\beta_{0}+\beta_{1} * Y_{t-1}+\beta_{2} *\left(T-\frac{N}{2}\right)+u_{t}
$$

Hypothesizes of unit root tests partaking in study are as follows:

$\mathrm{H}_{0}$ : Unit root exists.

$\mathrm{H}_{1}$ : Unit root does not exist.

Test results of ADF and PP that were implemented to series in this study have been shown in Table 2: 
Table 2. ADF Unit Root Tests

\begin{tabular}{|c|c|c|c|c|}
\hline \multirow{3}{*}{ Variables } & \multicolumn{4}{|c|}{$\overline{\text { ADF }}$} \\
\hline & \multicolumn{2}{|r|}{$\mathrm{C}$} & \multicolumn{2}{|c|}{$\mathrm{C}+\mathrm{T}$} \\
\hline & $\mathrm{I}(0)$ & $\mathrm{I}(1)$ & $\mathrm{I}(0)$ & $\mathrm{I}(1)$ \\
\hline $\operatorname{loggdp}$ & -0.223 & $-4.631^{* * * *}$ & -2.521 & $-4.556^{* * * *}$ \\
\hline logop & -0.029 & $-6.102^{* * * *}$ & -2.160 & $-5.579^{* * *}$ \\
\hline logcap & -1.362 & $-5.215^{* * * *}$ & -3.770 & $-5.223^{* * *}$ \\
\hline loglab & -1.466 & $-4.355^{* * * *}$ & -0.843 & $-4.442^{* * *}$ \\
\hline \multicolumn{5}{|c|}{ PP } \\
\hline & \multicolumn{2}{|r|}{$\mathrm{C}$} & \multicolumn{2}{|c|}{$\mathrm{C}+\mathrm{T}$} \\
\hline & $\mathrm{I}(0)$ & $\mathrm{I}(1)$ & $\mathrm{I}(0)$ & $\mathrm{I}(1)$ \\
\hline $\operatorname{loggdp}$ & -0.121 & $-4.678^{* * * *}$ & -2.614 & $-4.572^{* * *}$ \\
\hline logop & -0.029 & $-2.160^{* * *}$ & -6.108 & $-6.611^{* * *}$ \\
\hline logcap & -1.202 & $-8.891^{* * * *}$ & -3.019 & $-10.066^{* * * *}$ \\
\hline loglab & -1.454 & $-4.303^{* * * *}$ & -1.035 & $-4.281^{* * *}$ \\
\hline
\end{tabular}

Note: *, ** and *** have shown $\% 1, \% 5$ and $\% 10$ of significant levels, respectively.

According to ADF and PP unit root test results partaking in Table 2, it had been determined that all variables are stable in their first differences, also both two-unit tests show parallel results. Since all variables are stable in their first differences, cointegration relation between series had been searched by Johansen cointegration method.

\subsection{Johansen Cointegration Test}

Cointegration analysis has based on theory that there is long term relation between series even when series are not stable and this relation may be a stationary structure. In other words, being cointegrated of series has shown that every variable in system are impressed by common stochastic trend instead of specific external and permanent shocks. If cointegrated series are same-stationary, there may be cointegrated relation between series. Regression that was established due to series being influenced by same stochastic trend is meaningful regression rather than spurious regression (Tarl and Y1ldırım, 2009:100).

The economic interpretation of cointegration is that if two or more series, together with the stochastic trends, combine together to form a long-term equilibrium relationship, then these series move together over time and the difference between them remains static. Thus, the concept of cointegration indicates the existence of a long-term equilibrium that the economic system has converged over time (Harris, 1995).

Johansen method has been explained by below equation:

$X_{t}=\mu+\Pi_{1} X_{t-1}+\cdots+\Pi_{k} X_{t-k}+\varepsilon_{t}$

Hypothesizes related to whether there is cointegration between series or not are as follows:

$\mathrm{H}_{0}$ : There is not cointegration between series.

$\mathrm{H}_{1}$ : There is cointegration between series. 
Table 3. Johansen Cointegration Test Results

\begin{tabular}{|c|c|c|c|}
\hline \multicolumn{4}{|c|}{ Model; loggdp $\mathrm{p}_{\mathrm{t}}=\alpha_{0}+\alpha_{1} \log \mathrm{log}_{\mathrm{t}}+\alpha_{2} \log \operatorname{lab}_{\mathrm{t}}+\alpha_{3} \log \mathrm{cap} \mathrm{p}_{\mathrm{t}}+\mathrm{u}_{\mathrm{t}}$} \\
\hline \multicolumn{4}{|c|}{$\lambda_{\mathrm{iz}}$ statistic } \\
\hline Hypothesizes & Trace & Critical Value\%5 & Prob $^{\mathbf{a}}$ \\
\hline $\mathrm{H}_{0}: \mathrm{r}=0, \mathrm{H}_{1}: \mathrm{r} \geq 1$ & 63.069 & 47.856 & $0.001^{*}$ \\
\hline $\mathrm{H}_{0}: \mathrm{r} \leq 1, \mathrm{H}_{1}: \mathrm{r} \geq 2$ & 30.928 & 29.797 & $0.036^{* *}$ \\
\hline \multicolumn{4}{|c|}{$\lambda_{\max }$ statistic } \\
\hline Hypothesizes & Max & Critical Value \%5 & Prob $^{\mathbf{a}}$ \\
\hline $\mathrm{H}_{0}: \mathrm{r}=0, \mathrm{H}_{1}: \mathrm{r} \geq 1$ & 32.140 & 27.584 & $0.010^{* *}$ \\
\hline $\mathrm{H}_{0}: \mathrm{r} \leq 1, \mathrm{H}_{1}: \mathrm{r} \geq 2$ & 16.852 & 21.131 & 0.179 \\
\hline
\end{tabular}

Note: $*$, ** and $* * *$ have shown $\% 1, \% 5$ and $\% 10$ of significant levels, respect.

Johansen Cointegration Test results have been given in Table 3. When results in table were examined, it has been seen that there is a long-term relation between series in terms of both maximum eigenvalue test and trace test. Because of the maximum eigenvalue test and trace test values are bigger than the critical value in $0.05 \%$ significant level, it has shown that $\mathrm{H}_{0}$ hypothesis as that there is not cointegration was rejected in 5\% and $1 \%$ significant level. Therefore, cointegration relation is relevant between variables.

There is cointegration relation between variables and while these are first order stationary, guessing such this model by least square model has created deviations from specifications such as unbiased, consistent and efficiency of least square method. In addition, when characteristics of least square estimators have been destroyed, efficiency of applicable technique has been also destroyed and hypothesis tests have become invalid. Therefore, although two variables are cointegrated, relation between explanatory variables and error terms has shown up and it has created endogeneity problem. In this case, variables have lost their asymptotic characteristics. To deal with these problems, three methods have been suggested as FMOLS, CCR and DOLS (Berke, 2012:251).

Table 4. Long Range Factors Estimation Results

\begin{tabular}{|c|c|c|c|c|c|c|}
\hline \multicolumn{7}{|c|}{ Model; loggdp $\mathrm{t}_{\mathrm{t}}=\alpha_{0}+\alpha_{1} \log \mathrm{op}_{\mathrm{t}}+\alpha_{2} \log l \mathrm{~b}_{\mathrm{t}}+\alpha_{3} \log \mathrm{capt}+\mathrm{u}_{\mathrm{t}}$} \\
\hline \multirow[b]{2}{*}{$\begin{array}{l}\text { Independent } \\
\text { Variables }\end{array}$} & \multicolumn{2}{|l|}{ FMOLS } & \multicolumn{2}{|l|}{ CCR } & \multicolumn{2}{|l|}{ DOLS } \\
\hline & $\begin{array}{l}\text { Long Range } \\
\text { Factors }\end{array}$ & $\begin{array}{l}\text { Probability } \\
\text { value }\end{array}$ & $\begin{array}{l}\text { Long Range } \\
\text { Factors }\end{array}$ & $\begin{array}{l}\text { Probability } \\
\text { value }\end{array}$ & $\begin{array}{l}\text { Long Range } \\
\text { Factors }\end{array}$ & $\begin{array}{l}\text { Probability } \\
\text { value }\end{array}$ \\
\hline logop & $\begin{array}{c}0.186 \\
(3.591)\end{array}$ & $0.001^{*}$ & $\begin{array}{c}0.190 \\
(3.508)\end{array}$ & $0.001^{*}$ & $\begin{array}{c}0.258 \\
(3.287)\end{array}$ & $0.003^{*}$ \\
\hline logcap & $\begin{array}{c}0.124 \\
(2.007) \\
\end{array}$ & $0.053^{* * *}$ & $\begin{array}{c}0.121 \\
(1.812) \\
\end{array}$ & $0.079^{* * *}$ & $\begin{array}{c}0.041 \\
(0.398) \\
\end{array}$ & 0.695 \\
\hline loglab & $\begin{array}{c}0.825 \\
(2.456)\end{array}$ & $0.020^{* *}$ & $\begin{array}{c}0.810 \\
(2.469)\end{array}$ & $0.019^{* *}$ & $\begin{array}{c}0.943 \\
(2.153)\end{array}$ & $0.044^{* *}$ \\
\hline
\end{tabular}

Note: *, ** and *** have shown $\% 1, \% 5$ and $\% 10$ of significant levels, respect.

FMOLS, DOLS and CCR results that were used to test long range cointegration factors have been shown in Table 4. According to results of FMOLS, DOLS and CCR, factors of each three variables are positive and significant as statically. $1 \%$ increase happened in oil prices have raised the economic growth in between $0.018 \%-0.025 \%$ as $1 \%$ significant level according to results of each three models. But, $1 \%$ increase happened in capital variable has increased it as $0.12 \%$ in both two models (FMOLS, CCR). $1 \%$ increase in labor variable has also increased it in between $0,82 \%-0,94 \%$ as $5 \%$ significant level in each three models. 


\subsection{Granger Causality Test}

In the granger causality test, the direction of the causality relation between variables is being investigated. in other words, in the cause-effect relation, for example, if the delayed value of $Y$ is added to the regression of the variable $\mathrm{X}$ with respect to other variables along with their past values, the estimate of the variable X improves significantly (Granger, 1969, Gujarati, 2011:713).

Granger causality test that was made to determine the direction of relation between has been explained with the help of below equation.

$Y_{t}=\sum_{j=1}^{m} a_{j} X_{t-j}+\sum_{j=1}^{m} b_{j} Y_{t-j}+\varepsilon_{t}$

$Y_{t}=\sum_{j=1}^{m} c_{j} X_{t-j}+\sum_{j=1}^{m} d_{j} Y_{t-j}+\eta_{t}$

While " $\mathrm{m}$ " is showing lag length in this equation, it has been assumed that $\varepsilon_{t}$ and $\eta_{t}$ are independent from each other.

Hypothesizes determined for Granger Causality Test are as follows:

$\mathrm{H}_{0}$ : It is not Granger cause.

$\mathrm{H}_{1}$ : It is Granger cause.

Granger causality test had been used to determine the causality relation between oil prices and economic growth and results related to test has been shown in Table 5.

Table 5. Granger Causality Test Results

\begin{tabular}{|l|c|c|}
\hline \multicolumn{3}{|c|}{ Model; loggdp $\mathrm{p}_{\mathrm{t}}=\alpha_{0}+\alpha_{1} \operatorname{logop}_{\mathrm{t}}+\alpha_{2} \operatorname{loglab} \mathrm{b}_{\mathrm{t}}+\alpha_{3} \operatorname{logcap}_{\mathrm{t}}+\mathrm{u}_{\mathrm{t}}$} \\
\hline F statistic & Prob \\
\hline dloglab => loggdp & 4.083 & $0.027^{* *}$ \\
\hline dloggdp => loglab & 0.659 & 0.524 \\
\hline dlogop => loggdp & 7.176 & $0.003^{* * *}$ \\
\hline dloggdp => logop & 0.761 & 0.476 \\
\hline dlogcap =>loggdp & 2.519 & $0.098^{*}$ \\
\hline dloggdp =>logcap & 4.014 & $0.029^{* *}$ \\
\hline dlogop =>loglab & 0.096 & 0.908 \\
\hline dloglab =>logop & 3.041 & $0.063^{*}$ \\
\hline dlogcap =>loglab & 2.054 & 0.147 \\
\hline dloglab =>logcap & 4.092 & $0.027^{* *}$ \\
\hline dlogcap =>logop & 0.940 & 0.402 \\
\hline dlogop =>logcap & 6.574 & $0.004^{* * *}$ \\
\hline
\end{tabular}

Note: *,** and *** have shown $\% 1, \% 5$ and $\% 10$ of significant levels, respect.

When results in table were evaluated, it has been found that there is unidirectional causality relation between oil prices and economic growth. In other words, while oil prices affect economic growth, economic growth has not affected oil prices.

\section{Discussion/Conclusion}

The purpose of this study is to examine causality between oil prices and real GDP in Venezuela and to test long term relation between these two variables. Therefore, oil prices are going to be reason of economic growth. Direction of causality relation between variables has importance in determination of energy politics and correct politics should be applied according to direction of the relation. 
In conducted study, it had been determined that oil prices, GDP, capital and labor variables are not stationary series and they are first order integrated series by applied unit root tests. Johansen cointegration analysis that enables to search long term relation since series are same order integrated had been performed. In the analysis result, it had been established that series move together in long term. Then, Granger causality test had been done between series and it had been found that there is a unidirectional causality relation between oil prices and economic growth. For this reason, politics that was in direction to increase oil production in Venezuela are going to be effective on economic growth.

Oil, which is a part of basic energy resources, has a very important place in our daily life. Nearly all sectors use oil as input, either directly or indirectly. As a consequence of this dependence, oil prices have an impact on both the country and the world economy.

Oil is the most important energy source. Hence, increases in oil prices have indirect and direct implications on the economies of developed and developing countries. The negative effects of the increase in oil prices on the economy are increasing in direct proportion to the share of oil spending in national income and the fact that the country cannot turn to other energy sources.

Venezuela should develop more industrial sectors. The industrial sector should invest more in development, especially in the current economic system reforms should go to encourage foreign capital. The share of human capital investment should also be increased in order to raise quality human power. Work to be done in various areas should be encouraged. Nowadays, priority is given to the natural gas sector, which is increasing in importance.

\section{REFERENCES}

Abeysinghe, T. (2001). "Estimation of Direct and Indirect Impact of Oil Price on Growth", Economic Letters, 73, pp.147-153.

Alagöz, Mehmet, Nur Dilbaz A. and Akarsu Y. (2017). "Petrol Fiyatlarının Makro Ekonomi Üzerindeki Etkisi-Ülke Karşılaştırmaları ile Panel Veri Analizi”, KMÜ Sosyal ve Ekonomik Araştırmalar Dergisi 19 (33), pp.144-150, 2017.

Albaity, M. and Mustafa, H. (2018). "International and Macroeconomic Determinants of Oil Price: Evidence from Gulf Cooperation Council Countries", International Journal of Energy Economics and Policy, 2018, 8(1), pp.69-81.

Berke, B. (2012). “Döviz Kuru ve IMKB100 Endeksi İlişkisi: Yeni Bir Test”, Maliye Dergisi, Sayı:163, Temmuz-Aralık 2012.

Berument, H., Ceylan Nildag Başak and Doğan N. (2010). "The Impact of Oil Price Shocks on The Economic Growth of Selected Mena Countries”, The Energy Journal, Volume 31, pp.149-176.

Blanchard, Olivier and Gali J. (2007). "The Macroeconomic Effects of Oil Price Shocks: Why are the 2000s so Different from the 1970s?", National Bureau of Economic Research (NBER) Working Paper, 13368, pp.1-77.

Bozkurt, H. (2007). Zaman Serileri Analizi, Bursa: Ekin Kitabevi.

Brown, Stephen and Yücel Mine K. (1999). "Oil Prices and U.S. Aggregate Economic activity: A Question of Neutrality", Economic and Financal Review, pp.16-23.

Burbidge, John and Harrison A. (1984). "Testing for the Effects of Oil-Price Rises Using Vector Autoregressions", International Economic Review, Vol. 25(2), pp.459-84, June. 
Cunado, Juncal and Perez De Gracia F. (2003). "Do oil price shocks matter? Evidence for some European countries", Energy Econmics, Vol 25, pp. 137-154.

Dickey, David A. and Fuller Wayne A. (1979). "Distribution of the Estimators for Autoregressive Time Series with a Unit Root", Journal of The American Statistical Society, 75, pp.427-431.

Enders, W. (2004). Applied Econometrics Time Series, Newyork, John Wiley and Sons.

Ftiti, Zied, Guesmi Khaled, Teulon Frederic and Chouachi S. (2016). "Relationship Between Crude Oil Prices And Economic Growth In Selected OPEC Countries", The Journal of Applied Business Research, Volume 32, Number 1.

Granger, Clive William J. (1969). "Investigating Causal Relations by Econometric Models and Crossspectral Methods”, Econometrica, Vol. 37, No. 3. (Aug., 1969), pp. 424-438.

Gujarati, D. (2011). Temel Ekonometri, Çeviren: Ümit Şenesen, Gülay Günlük Şenesen, Literatür Yayıncilik.

Hamilton, Douglas J. (2009). "Understanding Crude Oil Prices", The Energy Journal, International Association for Energy Economics, Vol. 30(2), pp.179-206.

Hanabusa, K. (2009). "Causality Relationship between the Price of Oil and Economic Growth in Japan", Energy Policy, Vol.37, pp.1953-1957.

Harris, R. (1995). Using Cointegration Analysis In Econometric Modelling, T.J.Press (Padstow) Ltd: Great Britain.

Jayaraman, Tiru and Evan L. (2011). "Oil Price and Economic Growth in Small Pacific Island Countries”, Modern Economy, pp.153-162.

Lardic, Sandrine and Valerie M. (2006). "Oil prices and economic activity: An asymmetric cointegration approach”, Energy Economics, 34, pp.3910-3915.

Lardic, Sandrine and Valerie M. (2008). "Oil Prices And Economic Activity: An Asymmetric Cointegration Approach", Energy Economics, 30, pp.847-855.

Lienert, I. (1981). "The Macroeconomic Effects of the 1979/80 Oil Price Rise on Four Nordic Economies", Wiley on behalf of The Scandinavian Journal of Economics, Vol.83, No.2, pp.201219.

Lorde, Troy, Mahalia J., and Thomas C. (2009). "The Macroeconomic Effects of Oil Price Fluctuations on a Small Open Oil-Producing Country: The Case of Trinidad and Tobago". Energy Policy, 37(7), pp.2708-2716.

Miller, Isaac and Ratti R. (2009). "Crude oil and stock markets: Stability, instability, and bubbles", Energy Economics, 31(4), pp.559-568.

Nazir, Sidra and Hameed T. (2015). "Impact of Oil Price and Shocks on Economic Growth of Pakistan: Multivariate Analysis (Sectoral Oil Consumption)", Bus Eco J 6:182. doi:10.4172/21516219.1000182.

Papapetrou, E. (2001). "Oil Price Shocks, Stock Market, Economic Activitiy and Employment in Greece", Energy Economics, Vol.23, pp.511-532.

Perron, P. (1989). "The Great Crash, The Oil Price Shock, and The Unit Root Hypothesis", Econometrica, 57(2), pp.1361-1401.

Tarı, Recep and Yıldırım Durmuş Ç. (2009). "Döviz Kuru Belirsizliğinin İhracata Etkisi: Türkiye İçin Bir Uygulama", Yönetim ve Ekonomi 16/2, pp.95-105. 